\title{
Viability of Carica papaya L. Seeds by the Tetrazolium Test
}

\author{
Sara M. C. Carvalho ${ }^{1}$, Salvador B. Torres ${ }^{1}$, Erivanessa C. Sousa ${ }^{1}$, Danielle M. M. Sousa ${ }^{2}$, Kleane T. O. Pereira ${ }^{1}$, \\ Emanoela P. de Paiva ${ }^{1}$, Janete R. Matias ${ }^{1} \&$ Brenna R. V. dos Santos ${ }^{1}$ \\ ${ }^{1}$ Department of Plant Production, Federal Rural University of Semi-Arid, Mossoró, Brazil \\ ${ }^{2}$ Department of Environmental and Technological Sciences, Federal Rural University of Semi-Arid, Mossoró, \\ Brazil \\ Correspondence: Emanoela P. de Paiva, Federal Rural University of Semi-Arid, Rio Grande do Norte, Brazil. Tel: \\ 55-084-99806-0517. E-mail: emanuelappaiva@hotmail.com
}

Received: October 16, 2017

Accepted: December 6, 2017 Online Published: January 15, 2018

doi:10.5539/jas.v10n2p335

URL: https://doi.org/10.5539/jas.v10n2p335

\begin{abstract}
Germination test for papaya seeds demands thirty days to obtain the results, which is a long period for decision-making. Thus, rapid tests become essential tools to evaluate seed viability, and the tetrazolium test is an alternative for this purpose. Hence, this study aimed to establish the adequate procedure to apply this test, in order to reduce the time of evaluation of papaya seeds. For that, four tetrazolium solution concentrations $(0.05$, $0.1,0.5$ and $1 \%)$ and three staining times $\left(3,6\right.$ and 9 hours) were tested at temperatures of 35 and $40{ }^{\circ} \mathrm{C}$. The experimental design was completely randomized in $4 \times 3+1$ factorial scheme (concentrations $\times$ staining times + one control $=$ germination test). It was found that the tetrazolium test allows to evaluate the physiological quality of papaya seeds, thus reducing the time for decision-making. For the test, we recommend using the concentrations of $0.1 \%$ for 9 hours or $1 \%$ for 6 hours of staining, at temperature of $40^{\circ} \mathrm{C}$.
\end{abstract}

Keywords: Caricaceae, tropical fruits, rapid tests

\section{Introduction}

Papaya (Carica papaya L.) occupies a prominent place among the tropical fruits cultivated in Brazil and worldwide, due to the wide possibilities of utilization of the product and especially due to its composition (Jesus et al., 2016). Papaya production in Brazil in 2014 was equal to 1.58 million tons, equivalent to $16.67 \%$ of the global production (FAO, 2017), and the Bahia state is the largest national producer, followed by Espírito Santo and Minas Gerais, with productions of 718.7, 404.7 and 126.8 thousand tons, respectively, representing together approximately $80 \%$ of the Brazilian production in 2014 (IBGE, 2014).

The most cultivated papaya varieties in Brazil belong to the groups 'Solo' and 'Formosa'. 'Solo' group has fruits with reddish pulp and small size, weighing from 300 to $650 \mathrm{~g}$, whereas fruits of the 'Formosa' group exhibit reddish orange pulp, mean weight of 1,000 to $1,300 \mathrm{~g}$ and are mostly formed by commercial hybrids (Dias et al., 2011).

Papaya can be propagated through cuttings, grafting and seeds. This latter method has been the most used in the economic exploitation of the crop, because the other two propagation methods do not have any advantage from the perspective of either vigor and yield or maintenance of the desirable features (Andrade \& Jasper, 2013).

Seed quality evaluation through rapid tests that generate reproducible results has been a constant search of seed technologists and can help the decision-making regarding the use or disposal of lots, especially for species that require long periods for germination (Marcos-Filho, 2015). According to the Rules for Seed Evaluation, papaya requires 30 days to obtain this information through the standard germination test (Brasil, 2009). For Cunha and Gomes (2015), the delay to obtain results through the germination test, in some species, can be a limitation, especially when there is a demand for decision-making in the seed industry.

The tetrazolium test is based on the staining of living tissues in the presence of the solution of 2,3,5-triphenyltetrazolium chloride, which is reduced by the activity of dehydrogenase enzymes involved in the mitochondrial respiration activity. During respiration, hydrogen ions are released and react with the salt, which is colorless and soluble, forming triphenylformazan, a stable, non-diffusible, red-colored compound (Fogaça et al., 2011; Lazarotto et al., 2011). The efficiency of this test to evaluate seed viability depends on the development 
and use of a method adapted to each species, such as defining adequate conditions for pre-conditioning, preparation, staining and evaluation of the seeds (Pinto et al., 2009).

Studies on the tetrazolium test with cultivated species have already been conducted to propose adequate methodology for its use, such as França Neto, Krzyzanowski, and Costa (1998) with soybean (Glycine max L. Merr.); Lima et al. (2007) with melon (Cucumis melo L.); Nery et al. (2007) with watermelon (Citrullus lanatus Thunb. Matsum.); Cervi and Mendonça (2009) with cotton (Gossypium herbaceum L.); Gaspar-Oliveira et al. (2010) with castor bean (Ricinus communis L.); Silva et al. (2013) with sunflower (Helianthus annuus L.) and Rodrigues et al. (2015) with cowpea (Vigna unguiculata L. Walp.).

Given the importance of papaya as a fruit species and considering that the evaluation of its seeds' quality through germination test is time-consuming, this study aimed to establish an adequate methodology to apply the tetrazolium test, in order to reduce the time necessary to evaluate the viability of seeds of this species.

\section{Material and Methods}

Papaya seeds of the 'Havaí' variety, 'Solo' group, were removed from ten ripe fruits. The sarcotesta was removed by friction on a sieve and the seeds were dried immediately after (Cavalcante et al., 2014). Water content was determined through the method of the oven at $105 \pm 3{ }^{\circ} \mathrm{C}$, for 24 hours (Brasil, 2009), and the seeds were stored in a cold chamber $\left(17^{\circ} \mathrm{C}\right.$ and $60 \%$ relative air humidity) until the beginning of the experiment.

Based on preliminary tests, the seeds were pre-moistened in paper towel for $2 \mathrm{~h}$ and longitudinally cut using blades, but without separating their parts, to facilitate evaluation. Subsequently, the seeds were placed in 50-mL plastic cups and mixed with the 2,3,5-triphenyltetrazolium chloride solution at four concentrations $(0.05,0.1,0.5$ and $1 \%$ ) for three staining times $\left(3,6\right.$ and 9 hours) at temperatures of $35^{\circ} \mathrm{C}$ and $40{ }^{\circ} \mathrm{C}$, in a Biochemical Oxygen Demand (B.O.D.) chamber in the absence of light. Four subsamples of 25 seeds wereused in each combination. After each staining time, the tetrazolium solution was drained, the seeds were washed in running water, mixed with water and maintained in the refrigerator until the moment of evaluation.

Seeds were evaluated using a desktop magnifying glass and classified as viable or unviable, according to the color standard indicated by França-Neto et al. (1998): light pink (healthy tissue); intense red (deteriorating tissue) and without color (dead tissue). Not only the color, but also site, intensity and extension were considered. Results were expressed in percentage of viable seeds.

To obtain a standard for result comparison, a germination test was conducted simultaneously to the tetrazolium test, using four subsamples of 50 seeds arranged on paper towel moistened with distilled water at proportion of 2.5 times the weight of the dry paper at alternated temperature of $20-35{ }^{\circ} \mathrm{C}$ in a B.O.D. chamber. Seeds were evaluated 30 days after sowing and the results were expressed in percentage of normal seedlings (Brasil, 2009).

The experimental design was completely randomized in $4 \times 3+1$ factorial scheme (four solution concentrations $\times$ three staining times + one control $=$ germination test $)$ at two temperatures $\left(35^{\circ} \mathrm{C}\right.$ and $\left.40{ }^{\circ} \mathrm{C}\right)$. The means of viable seeds obtained in the tetrazolium test were compared by Tukey test $(\mathrm{p} \leq 0.05)$, whereas the means of viableseeds obtained in the germination test (control) were compared by Dunnett test $(p \leq 0.05)$, following the recommendations of Banzatto and Kronka (2006). Statistical analyses were performed using the program ASSISTAT 7.7, Beta version (Silva \& Azevedo, 2002).

\section{Results and Discussion}

After drying, the seeds showed water content of $8.9 \%$ and the germination test resulted in $69 \%$ of normal seedlings.

The percentages of viable seeds obtained in the tetrazolium test in the different treatments (concentration $\times$ exposure time) and germination test, at temperature of 35 and $40{ }^{\circ} \mathrm{C}$ are presented in Tables 1 and 2 , respectively.

For the temperature of $35^{\circ} \mathrm{C}$ (Table 1), the highest means of viability were found when seeds were exposed to the highest solution concentrations $(0.5 \%$ and $1 \%)$. At the lowest concentrations $(0.05 \%$ and $0.1 \%)$, viability was null, regardless of the seed exposure time. Although all treatments differed from the control at this temperature, the combination of highest concentration (1\%) and longest time ( 9 hours) resulted in high percentage of viable seeds $(84 \%)$. 
Table 1. Means of viability of Carica papaya L. seeds by the tetrazolium test conducted at different concentrations and staining times, at temperature of $35^{\circ} \mathrm{C}$.

\begin{tabular}{lllll}
\hline \multirow{2}{*}{ Periods (h) } & \multicolumn{4}{c}{ Concentrations (\%) } \\
\cline { 2 - 5 } & $0.05^{*}$ & 0.1 & 0.5 & 1 \\
\hline 3 & $0.0 \mathrm{aAy}$ & $0.0 \mathrm{aAy}$ & $2.0 \mathrm{cAy}$ & $1.0 \mathrm{cAy}$ \\
6 & $0.0 \mathrm{aCy}$ & $0.0 \mathrm{aCy}$ & $42.0 \mathrm{aAy}$ & $30.0 \mathrm{bBy}$ \\
9 & $0.0 \mathrm{aCy}$ & $0.0 \mathrm{aCy}$ & $32.0 \mathrm{bBy}$ & $86.0 \mathrm{aAy}$ \\
\hline Germination $(\%) 69 \mathrm{z}$ & & &
\end{tabular}

Note. * Means followed by the same letter, uppercase in the row (A, B, C) and lowercase in the column (a, b, c), do not differ significantly by Tukey test at 0.05 probability level. Means followed by the same letter (z, y), between germination (control - germination test) and viability obtained in the tetrazolium test, do not differ significantly by Dunnett test at 0.05 probability level.

At temperature of $40{ }^{\circ} \mathrm{C}$ (Table 2$)$, among the tested concentrations only the lowest one $(0.05 \%)$ did not promote efficiency in any of the testedtimes of exposure. At 0.1 and $0.5 \%$ concentrations, the means of viability were statistically equal to those of the germination test when the seeds were exposed to 9 hours of staining. The $1 \%$ concentration, except for the 3-h time, was favorable to seed evaluation. In the 9-h staining time, it was possible to observe the highest means of viability, which did not differ from the control, except at the lowest concentration $(0.05 \%)$. As occurred for the temperature of $35^{\circ} \mathrm{C}$, the 3 -h time was not favorable to seed quality evaluationat any of the concentrations. However, the increase in the exposure time to 6 hours promoted favorable evaluation at the highest concentration $(1 \%)$.

Table 2. Means of viability of Carica papaya L. seeds by the tetrazolium test conducted at different concentrations and staining times, at temperature of $40^{\circ} \mathrm{C}$.

\begin{tabular}{lllll}
\hline \multirow{2}{*}{ Periods (h) } & \multicolumn{4}{c}{ Concentrations (\%) } \\
\cline { 2 - 5 } & $0.05^{*}$ & 0.1 & 0.5 & 1 \\
\hline 3 & $0.0 \mathrm{aBy}$ & $0.0 \mathrm{cBy}$ & $22.0 \mathrm{bAy}$ & $11.0 \mathrm{bABy}$ \\
6 & $0.0 \mathrm{aBy}$ & $18.0 \mathrm{bBy}$ & $17.0 \mathrm{bBy}$ & $62.0 \mathrm{aAz}$ \\
9 & $0.0 \mathrm{aCy}$ & $63.0 \mathrm{aBz}$ & $82.0 \mathrm{aAz}$ & $71.0 \mathrm{aABz}$ \\
\hline Germination $(\%) 69 \mathrm{z}$ & & &
\end{tabular}

Note. * Means followed by the same letter, uppercase in the row (A, B, C) and lowercase in the column (a, b, c), do not differ significantly by Tukey test at 0.05 probability level. Means followed by the same letter (z, y), between germination (control - germination test) and viability obtained in the tetrazolium test, do not differ significantly by Dunnett test at 0.05 probability level.

Studies conducted with the tetrazolium test demonstrate highly variable results according to the studied species. While some are sensitive to low concentrations of the salt, papaya seeds in the present study required higher concentrations to develop a satisfactory color. The same could be observed for seeds of peanut (Arachis hypogaea L.) (Carvalho et al., 2009); black oat (Avena strigosa Sckreb.) and white oat (Avena sativa L.) (Souza et al, 2009, 2010) and barley (Hordeum vulgare L.) (Grzybowski et al., 2012). However, the concentration is also related to the time of seed exposure to the solution and they usually exhibit an inversely proportional relationship. This was clearly evident at temperature of $40{ }^{\circ} \mathrm{C}$ (Table 2), for which the 3-h time was inefficient at all concentrations, whereas the combinations of 6 hours at $1 \%$ and 9 hours at $0.1,0.5$ and $1 \%$ were statistically equal to the results ofthe germination test.

The temperature of $40{ }^{\circ} \mathrm{C}$ led to results statistically equal to those of the germination test, even at lower concentrations $(0.1$ and $0.5 \%)$, which did not occur for the temperature of $35^{\circ} \mathrm{C}$. This fact can be explained by the increase in the temperature of staining, corroborating AOSA (2009), which claims that seed color is more rapidly established at higher temperatures.

No studies were found on tetrazolium test for species of the Caricaceae family; thus, it was not possible to compare the behavior regarding the concentration, exposure time and color patterns of the seeds. Figure 1 shows some color patterns observed during the evaluation. In viable seeds, the tissues were light pink or bright red, 
indicating living, firm and vigorous tissue. On the other hand, unviable seeds assumed a milky white color (partial or total), suggesting dead tissue, or intense red color in its entire extension, indicating an accelerated process of tissue deterioration.

A

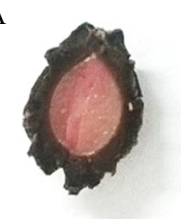

$\mathrm{C}$

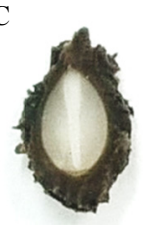

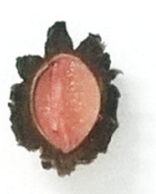

$\mathrm{D}$

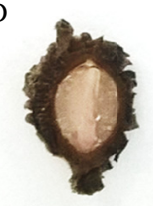

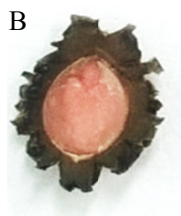
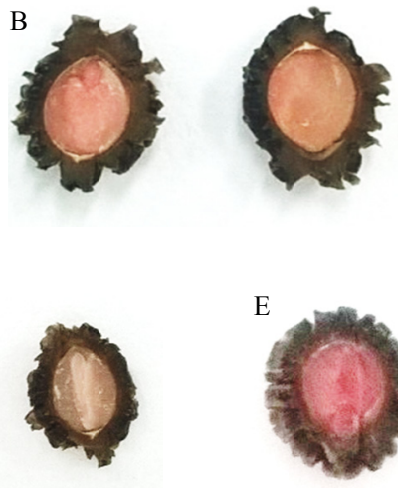

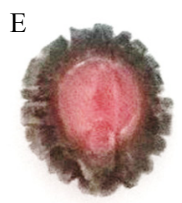

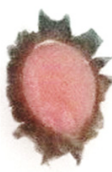

Figure 1. Carica papaya L. seeds considered as viable by the tetrazolium test: seeds with light pink color (A); bright red color (B) and unviable: seeds completely uncolored (C); with discolored regions (D) and intense red color in the entire extension (E)

The temperature of $35^{\circ} \mathrm{C}$ did not favor the evaluation of papaya seeds, because color development was difficult and many seeds did not stain, or such color was weak and not uniform. At this temperature, the values of viability were not consistent with that found for germination. In this case, what occurred was that many viable seeds were classified as unviable due to a failure in the staining process.

Although at temperature of $40{ }^{\circ} \mathrm{C}$ some treatments also made the evaluation difficult for not favoring an adequate color, the interpretation of the results was visually easier than at $35{ }^{\circ} \mathrm{C}$, because the seeds showed stronger and more uniform color. Some studies with cultivated species have also demonstrated positive response for the staining at $40^{\circ} \mathrm{C}$, such as those using seeds of zucchini (Curcubita pepo L.) (Barros et al., 2005); cotton (Gossypium hirsutum) (Cervi et al., 2009); peanut (Arachishy pogaea) (Carvalho et al., 2009); jatropha (Jatropha curcas L.) (Pinto et al., 2009); black oat (Avena strigosa) and white oat (Avena sativa) (Souza et al., 2009, 2010); cucumber (Cucumis sativus L.) (Lima et al. 2010); wheat (Titricum aestivum L.) (Carvalho et al., 2013) and sorghum (Sorghum bicolor L. Moench.) (Carvalho et al., 2014).

Flores et al. (2015), working with rapeseed (Brassica napus L.) seeds, using concentrations of 0.5 and $1.0 \%$ at $30{ }^{\circ} \mathrm{C} / 0.2,0.5$ and $1.0 \%$ at $40{ }^{\circ} \mathrm{C}$, for 2,4 and $6 \mathrm{~h}$, found better results in the test at $0.5 \%$ concentration for $6 \mathrm{~h}$ at $40{ }^{\circ} \mathrm{C}$, demonstrating a behavior very similar to that found in the present study, regarding the response of the seeds under high concentration, long exposure time and high temperature.

Although the data from the present study demonstrate the possibility of seed viability evaluation through four different treatments at $40{ }^{\circ} \mathrm{C}$ (Table 2), one should opt for the combinations of $1 \%$ for $6 \mathrm{~h}$, which provides an evaluation in shorter time, or $0.1 \%$ for $9 \mathrm{~h}$, which allows to use a lower quantity of reagent.

\section{Conclusions}

The time forviability evaluation of papaya seeds can be reduced by the tetrazolium test, which should be conducted at concentrations of $0.1 \%$ for $9 \mathrm{~h}$ or $1 \%$ for $6 \mathrm{~h}$ of staining, at $40{ }^{\circ} \mathrm{C}$.

\section{Reference}

Andrade, R. A., \& Jasper, S. P. (2013). Temperatura na emergência de quatro variedades de mamoeiro. Comunicata Sci., 4(4), 401-406.

AOSA (Association of Official Seed Analysis). (2009). Seed vigour testing handbook (p. 334). East Lansing: AOSA.

Banzatto, D. A., \& Kronka, S. N. (2006). Experimentação agrícola (4th ed., p. 237). Jaboticabal: Funep. 
Barros, D. I., Dias, D. C. F. S., Bhering, M. C., Dias, L. A. S., \& Araújo, E. F. (2005). Uso do teste de tetrazólio para avaliação da qualidade fisiológica de sementes de abobrinha. Rev. Bras. de Sem., 27(2), 165-171. https://doi.org/10.1590/S0101-31222005000200024

Brasil, Ministério da Agricultura, Pecuária e Abastecimento. (2009). Secretaria de Defesa Agropecuária. Coordenação Geral de Apoio Laboratorial. Regras para análise de sementes (p. 395). Brasília, DF: ACS.

Carvalho, N. M., Silva, J. B., Silveira, C. M., \& Horvat, R. A. (2009). Método alternativo para submeter sementes de amendoim à solução de tetrazólio. Rev. Bras. de Sem., 31(1), 18-22. https://doi.org/10.1590/ S0101-31222009000100002

Carvalho, T. C., Grzybowski, C. R. S., Ohlson, O. C., \& Panobianco, M. (2014). Adaptation of the tetrazolium test method for estimating the viability of sorghum seeds. J. of Seed Sci., 36(2), $246-252$. https://doi.org/10.1590/2317-1545

Carvalho, T. C., Krzyzanowski, F. C., Ohlson, O. C., \& Panobianco, M. (2013). Tetrazolium test adjustment for wheat seeds. J. of Seed Sci., 35(3), 361-367. https://doi.org/10.1590/S2317-15372013000300013

Cavalcante, J. A., Pereira, N. A. E., Nobre, R. G., Lopes, K. P., \& Marques, K. M. (2014). Qualidade fisiológica de sementes de mamão submetidas a diferentes métodos de remoção da sarcotesta. Rer. Ver. de Agro. e Desen. Sus., 9(2), 285-290. https://doi.org/10.18378/rvads.v9i2.2887

Cervi, F., \& Mendonça, E. A. F. (2009). Adequação do teste de tetrazólio para sementes de algodoeiro. Ver. Bras. de Sem., 31(1), 177-186. https://doi.org/10.1590/S0101-31222009000100020

Cunha, M. C. L., \& Gomes, I. H. R. A. (2015). Viabilidade de sementes de Erythrina velutina Willd. pelo teste de tetrazólio. Rev. Nativa, 3(3), 196-200. https://doi.org/10.14583/2318-7670.v03n03a08

Dias, N. L. P., Oliveira, E. J., \& Dantas, E. J. (2011). Avaliação de genótipos de mamoeiro com uso de descritores agronômicos e estimação de parâmetros genéticos. Pesq. Agropec. Bras., 46(1), 1471-1479. https://doi.org/10.1590/S0100-204X2011001100008

FAO (Food and Agriculture Organization). (2017). FAOSTAT Database. Retrieved from http://faostat.fao.org/ site/339/default.aspx

Flores, M. F., Grzybowski, C. R. D. S., Pazolini, K., Possenti, J. C., \& Panobianco, M. (2015). Criteria for implementation of a tetrazolium test in canola seeds. J. of Seed Sci., 37(4), 222-227. https://doi.org/10.1590/ 2317-1545v37n4153255

Fogaça, C. A., Krohn, N. G., Souza, M. A., \& Paula, R. C. (2011). Teste de tetrazólio em sementes de Copaifera langsdorffii e Schizolobium parahyba. Floresta, 41(4), 895-904. https://doi.org/10.5380/rf.v41i4.25352

França Neto, J. B., Kryzanowski, F. C., \& Costa, N. P. (1998). O teste de tetrazólio em sementes de soja (p. 72). Londrina: EMBRAPA/CNPSO. Retrieved from http://www.agrolink.com.br/downloads/TRETRAZ\%C3\% 93LIO.pdf

França Neto, J. B., Krzyzanowski, F. C., \& Costa, N. P. (1999). Metodologia do teste de tetrazólio em sementes de soja. In F. C. Krzyzanowski, R. D. Vieira, \& J. B. França Neto (Eds.), Vigor de sementes: conceitos e testes (pp. 1-28). Londrina: ABRATES.

Gaspar-Oliveira, C. M., Martins, C. C., \& Nakagawa, J. (2009). Concentração da solução de tetrazólio e período de coloração do teste para sementes de mamoneira. Rev. Bras. de Sem., 31(3), 38-47. https://doi.org/10.1590/S0101-31222009000300004

Grzybowski, C. R. S., Ohlson, O. C., Silva, R. C., \& Panobianco, M. (2012). Viability of barley seeds by the tetrazolium test. Rev. Bras.de Sem., 34(1), 47-54. https://doi.org/10.1590/S0101-31222012000100006

IBGE (Instituto Brasileirode Geografiae Estatística). (2014). Grupo de Coordenação de Estatísticas Agropecuárias - GCEA/IBGE; Diretoria de Pesquisas, Coordenação de Agropecuária, Levantamento Sistemático da Produção Agrícola - LSPA.

Jesus, V. A. M., Araújo, E. F., Neves, A. A., Santos, F. L., Dias, L. A. D. S., \& Silva, R. F. D. (2016). Ratio of seeds and sodium hypochlorite solution on the germination process of papaya seeds. Jour. of Seed Sci., 38(1), 57-61. https://doi.org/10.1590/2317-1545v38n1151150

Lazarotto, M., Piveta, G., Muniz, M. F. B., \& Reiniger, L. R. S. (2011). Adequação do teste de tetrazólio para avaliação da qualidade de sementes de Ceiba speciosa. Sem.: Ciên. Agrá., 32(4), 1243-1250. https://doi.org/ $10.5433 / 1679-0359.2011 \mathrm{v} 32 \mathrm{n} 4 \mathrm{p} 1243$ 
Lima, C. B., Bellettini, N. M. T., Janani, J. K., Silva, A. S., Amador, T. S., Vieira, M. A. V., \& Cheirubim, A. P. (2007). Metodologias do teste de tetrazólio para sementes de melão (Cucumis melo L.). Rev. Bras. de Biociências, 5(2), 744-746.

Lima, L. B., Pinto, T. L. F., \& Novembre, A. D. L. C. (2010). Avaliação da viabilidade e do vigor de sementes de pepino pelo teste de tetrazólio. Rev. Bras. de Sem., 32(1), 60-68. https://doi.org/10.1590/S0101-3122201 0000100007

Marcos-Filho, J. (2015). Fisiologia de sementes de plantas cultivadas (2th ed., p. 660). Londrina: ABRATES.

Nery, M. C., Carvalho, M. L. M., \& Oliveira, L. M. (2007). Teste de tetrazólio para avaliação da qualidade fisiológica de sementes de melancia. Sem. Ciên. Agrá., 28(3), 365-372. https://doi.org/10.5935/1806-6690. 20150048

Pinto, T. L. F., Brancalion, P. H. S., Novembre, A. D. L. C., \& Cicero, S. M. (2008). Avaliação da viabilidade de sementes de coração-de-negro (Poecilanthe parviflora Benth. - Fabaceae-Faboideae) pelo teste de tetrazólio. Rev. Bras. de Sem., 30(1), 208-214. https://doi.org/10.1590/S0101-31222008000100026

Pinto, T. L. F., Filho, J. M., Forti, V. A., Carvalho, C., \&Gomes Júnior, F. G. (2009). Avaliação da viabilidade de sementes de pinhão manso pelo teste de tetrazólio e de raios X. Rev. Bras. de Sem., 31(2), 195-2001. https://doi.org/10.1590/S0101-31222009000200023

Rodrigues, A. P. M., Mendonça Junior, A. F., Torres, S. B., Nogueira, N. W., \& Freitas, R. M. O. (2015). Teste de tetrazólio para avaliação da qualidade fisiológica de sementes de Vigna unguiculata (L.) Walp. Rev. Ciên. Agro., 46(3), 638-644. https://doi.org/10.5935/1806-6690.20150048

\section{Copyrights}

Copyright for this article is retained by the author(s), with first publication rights granted to the journal.

This is an open-access article distributed under the terms and conditions of the Creative Commons Attribution license (http://creativecommons.org/licenses/by/4.0/). 